\title{
Physiological performance of wheat seeds as a function of moisture content at harvest and storage system ${ }^{1}$
}

\author{
Maurício Albertoni Scariot ${ }^{2}$, Lauri Lourenço Radünz ${ }^{2}$, \\ Rafael Gomes Dionello², Indianara Müller ${ }^{2}$, Patricia Mara de Almeida ${ }^{3}$
}

\section{ABSTRACT}

The physiological performance of wheat seeds may be influenced by the harvest season and storage system. This study aimed at evaluating the physiological performance of wheat seeds as a function of different moisture contents at harvest, with later storage under hermetic and conventional systems. Harvest was performed when the seeds reached moisture contents of $28.6 \%, 18.5 \%$ and $12.9 \%$. Subsequently, they were stored for 240 days, in both systems, at room temperature. The evaluation of seed physiological performance was carried out by germination and vigor tests, shoot length and dry matter of seedlings. The germination of wheat seeds stored under the hermetic system increased up to 180 days of storage, due to the seed dormancy breaking, with a subsequent decrease of the values, while those stored under the conventional system showed a linear decrease of germination throughout the storage. The hermetic system provided an increase in seed vigor up to 120 days of storage and, after this period, there was a reduction of the values. The conventional system promoted a linear reduction of seed vigor throughout the storage, except for the results obtained in the tests of first germination count and germination speed index, which showed an increase up to 60 days of storage. Harvest delay negatively influenced seed germination and vigor, regardless of time and storage system. The combination of harvest anticipation and hermetic storage improves the physiological performance of seeds over time.

KEYWORDS: Triticum aestivum L.; harvest anticipation; hermetic storage; conventional storage.

\section{INTRODUCTION}

Wheat (Triticum aestivum L.) is one of the main grains consumed in the world, being one of the crops of major importance for food security (Walia 2015). World wheat consumption is estimated at

\section{RESUMO}

Desempenho fisiológico de sementes de trigo em função do teor de água na colheita e sistema de armazenamento

O desempenho fisiológico de sementes de trigo pode ser influenciado pela época de colheita e pelo sistema de armazenamento. Objetivou-se avaliar o desempenho fisiológico de sementes de trigo, em função de diferentes teores de água na colheita, com posterior armazenamento em sistemas hermético e convencional. A colheita foi realizada quando as sementes atingiram teores de água de $28,6 \%, 18,5 \%$ e $12,9 \%$. Posteriormente, as mesmas foram armazenadas por 240 dias, sob dois sistemas, à temperatura ambiente. A avaliação de desempenho fisiológico das sementes foi realizada pelos testes de germinação e vigor, comprimento da parte aérea e matéria seca das plântulas. A germinação de sementes de trigo armazenadas em sistema hermético aumentou até 180 dias de armazenamento, devido à quebra de dormência, com subsequente queda nos valores, enquanto as armazenadas sob sistema convencional apresentaram diminuição linear na germinação ao longo do armazenamento. O sistema hermético proporcionou aumento no vigor das sementes até 120 dias de armazenamento e, após este período, houve redução nos valores. O sistema convencional promoveu a redução linear do vigor das sementes ao longo do armazenamento, com exceção dos resultados demonstrados nos testes de primeira contagem de germinação e índice de velocidade de germinação, que apresentaram aumento até 60 dias de armazenamento. $\mathrm{O}$ atraso na colheita influenciou negativamente a germinação e vigor das sementes, independentemente do tempo e do sistema de armazenamento. A combinação de antecipação da colheita e armazenamento hermético melhora o desempenho fisiológico de sementes ao longo do tempo.

PALAVRAS-CHAVE: Triticum aestivum L.; antecipação de colheita; armazenamento hermético; armazenamento convencional.

739.7 million tons, with a production rated at 751.2 million tons of grains for the 2016/2017 crop (USDA 2016). In Brazil, the estimated wheat production for the $2016 / 2017$ crop is 5.2 million tons, being the southern region the largest producer, with 4.5 million tons (Conab 2017).

1. Manuscript received in Sep./2017 and accepted for publication in Dec./2017 (http://dx.doi.org/10.1590/1983-40632017v4749550).

2. Universidade Federal do Rio Grande do Sul, Faculdade de Agronomia, Departamento de Fitossanidade, Porto Alegre, RS,

Brasil.E-mails: mauricioalbertoniscariot@gmail.com, laurilr@gmail.com, rafdionello@hotmail.com, mutymuller@hotmail.com. 3. Universidade Federal da Fronteira Sul, Erechim, RS, Brasil.E-mail: patimara97@hotmail.com. 
The physiological performance is one of the main parameters considered for the classification of seed quality. The maximum physiological seed quality potential is observed at its maturity, which tends to reduce if harvest is delayed, depending on the intensity of climatic conditions, such as the relative humidity and air temperature to which they are exposed in the field. Thus, the delay in seed harvest may negatively affect the physiological performance. Therefore, the adequate knowledge of harvest season is of paramount importance. The anticipation of harvest, besides reducing the risks of seed deterioration in the field, may provide gains in quality, since seeds are harvested closer to their physiological maturity (Farrer et al. 2006).

Besides the harvest season, storage conditions are also extremely important for the maintenance of seed physiological performance from the field. Under inadequate conditions, seeds may suffer a considerable loss in quality up to the sowing time. One of the factors that may influence storage quality is the ability of the system to avoid gas exchange with ambient air, since it directly influences the respiratory rates of the seeds. Thus, the hermetic storage may conserve the seeds for a longer period of time, in comparison to the conventional storage, because it diminishes the gas exchanges between the seed mass and the external environment, thus reducing the respiratory rate, the attack of pests and, consequently, deterioration (Jonfia-Essien et al. 2010). Moreover, the physical, physiological and sanitary status of seeds coming from the field may influence the quality of the storage, since degraded or deteriorated seeds, due to delay in harvest or other factors, result in a lower conservation capacity and higher quality losses over time (Deliberali et al. 2010).

Some studies have analyzed the physiological performance of wheat seeds during storage, as a function of temperature, relative humidity and seed moisture content, as well as different packaging and storage systems (Strelec et al. 2010, Chattha et al. 2012, Petrenko 2014). However, studies on the influence of delays in wheat seed harvest, as well as the association of different harvest moisture contents with hermetic storage on the physiological performance of the seeds over time, are scarce.

Therefore, this study aimed at evaluating the physiological performance of wheat seeds, right after drying and during storage, as a function of different moisture contents at harvest and as a function of the storage system (hermetic or conventional).

\section{MATERIAL AND METHODS}

The wheat seeds (BRS Parrudo cultivar) were obtained from the experimental area of the Colégio Agrícola Ângelo Emílio Grando, in Erechim, Rio Grande do Sul state, Brazil, during the 2015 crop season. The cultivation was carried out under a no-tillage system, with fertilization, as well as phytosanitary treatments (Cunha \& Caierão 2014).

The experiment was conducted at the Universidade Federal da Fronteira Sul, in Erechim, under a completely randomized design, arranged in a $3 \times 2 \times 5$ factorial scheme (harvest moisture x storage system $\mathrm{x}$ storage time), with four replications per treatment. The seeds were harvested manually when moisture contents of $28.6 \%, 18.5 \%$ and $12.9 \%$ w.b. were reached. In order to minimize the seed mechanical damage at threshing, the ears obtained from the harvest with a moisture content of $28.6 \%$ were submitted to pre-drying $\left(38{ }^{\circ} \mathrm{C}\right)$ in an oven with forced-air circulation, until the seeds reached a moisture content of approximately $20 \%$ w.b. The material coming from the other harvests was sent directly to threshing, which was carried out with the use of a plot thresher. After that, the seeds were dried in an oven with forced-air circulation at a maximum temperature of $38^{\circ} \mathrm{C}$, until they reached a moisture content of around $12 \%$ w.b.

The beginning of the storage occurred between 10 and 30 November 2015, due to the harvest times. Storage was carried out under two systems: hermetic and conventional. Polyethylene terephthalate (PET) bottles, with volume of $900 \mathrm{~cm}^{3}$, and kraft paper bags of 2,500 $\mathrm{cm}^{3}$ were used for the hermetic and conventional systems, respectively. A total of 120 experimental units, with $750 \mathrm{~g}$ of seeds each, were evaluated. This procedure was adopted to avoid the leakage of the PET bottles, when samples were taken during storage, thus avoiding their replacement.

The seeds were kept at room temperature for 240 days, with a bi-weekly collection of temperature and relative humidity, using a digital thermohygrometer (Figure 1).

The average temperature at the storage site was $20.5^{\circ} \mathrm{C}$, ranging from $13{ }^{\circ} \mathrm{C}$ to $24.5^{\circ} \mathrm{C}$, during the 240 days of the experiment. From the 165 th day of storage, approximately, there was a drop 


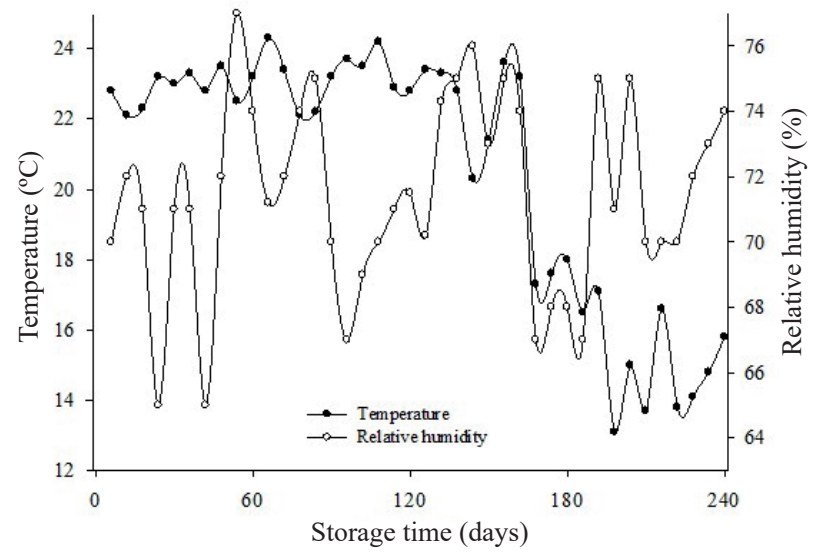

Figure 1. Air temperature and relative humidity, during storage under natural conditions.

in temperature, due to the beginning of winter, responsible for the greater thermal amplitude during storage. The air relative humidity varied between $64 \%$ and $77 \%$, with an average of $71.1 \%$.

For the seed physiological performance analyses, the samples were collected immediately after drying (time zero) and then at 60-day intervals, until the end of the period of 240 days.

The seed moisture content was determined in triplicates by the oven method at $105 \pm 3{ }^{\circ} \mathrm{C}$, for $24 \mathrm{~h}$ (Brasil 2009). The germination test was conducted on Germitest paper rolls soaked in distilled water in the proportion of 2.5 times their weight. The Germitest papers were kept in a germination chamber (Tecnal model TE-405) at $20 \pm 3{ }^{\circ} \mathrm{C}$, with a photoperiod of $12 \mathrm{~h}$. Four hundred seeds per replicate were used, distributed in eight subsamples of 50 seeds. The evaluations were carried out according to the Brazilian Rules for Seed Analysis (Brasil 2009).

The first germination count was performed with the germination test. Evaluations occurred on the 4th day after sowing, by counting the number of normal seedlings (Brasil 2009). The germination speed index was also carried out simultaneously to the germination test, by counting the number of normal germinated seeds per day, from sowing to the 8th day (Maguire 1962).

For the accelerated aging test, the seeds were placed in a gerbox containing $50 \mathrm{~mL}$ of distilled water, suspended with a grid and conditioned in a BOD chamber at $41{ }^{\circ} \mathrm{C}$, for $72 \mathrm{~h}$ (Marcos-Filho et al. 1987). After this stage, the test was conducted as described for the germination test, and the number of normal seedlings was evaluated on the 4th day after sowing. The cold test was conducted on Germitest paper rolls, likewise the germination test. However, the rolls were previously packed in plastic bags and set at $10{ }^{\circ} \mathrm{C}$, for seven days, in a BOD chamber (Loeffler et al. 1985). Then, they were placed in the germinating chamber at $20{ }^{\circ} \mathrm{C}$, for four days. After this period, the normal seedlings were counted.

The shoot length and dry matter were determined together with the germination test. The shoot length was determined by measuring, with the aid of a ruler graduated in millimeters, the shoots of 15 seedlings randomly collected in each roll. Also, for determining the dry matter, the endosperm was excised from the normal seedlings, which were then oven dried at $65{ }^{\circ} \mathrm{C}$, until constant weight. For the vigor tests, only the seedlings that had at least $1 \mathrm{~cm}$ of shoot and root protrusion were considered normal.

The data were submitted to variance analysis by the F test $(\mathrm{p} \leq 0.05)$. The averages of the qualitative variables were compared by the Tukey test $(p \leq 0.05)$ and the quantitative variables were submitted to regression analysis. For the quantitative factor, the models were adopted based on the significance of the regression coefficients, with the application of the t-test at $5 \%$, as well as the coefficient of determination and the biological phenomenon. The Statistica 10.0 software was used to perform statistical analyses and the SigmaPlot version 10.0 for the graphical representation of the data.

\section{RESULTS AND DISCUSSION}

According to the $\mathrm{F}$ test $(\mathrm{p} \leq 0.05)$, there was an interaction among the factors moisture content in the harvest, time and storage systems for all variables analyzed. Grains stored in the hermetic system, for all harvest conditions, did not show significant differences in the moisture content during the storage period, except for the harvest with a moisture content of $12.9 \%$ w.b., which increased during the storage period (Figure 2a). The grains stored in the conventional system showed an increase in moisture content up to 120 days for the three levels of harvest moisture. After this period, the moisture content of the grains oscillated according to the temperature and air relative humidity, tending to the hygroscopic equilibrium.

The results may be attributed to the permeability of each storage system. Hermetic systems make the 


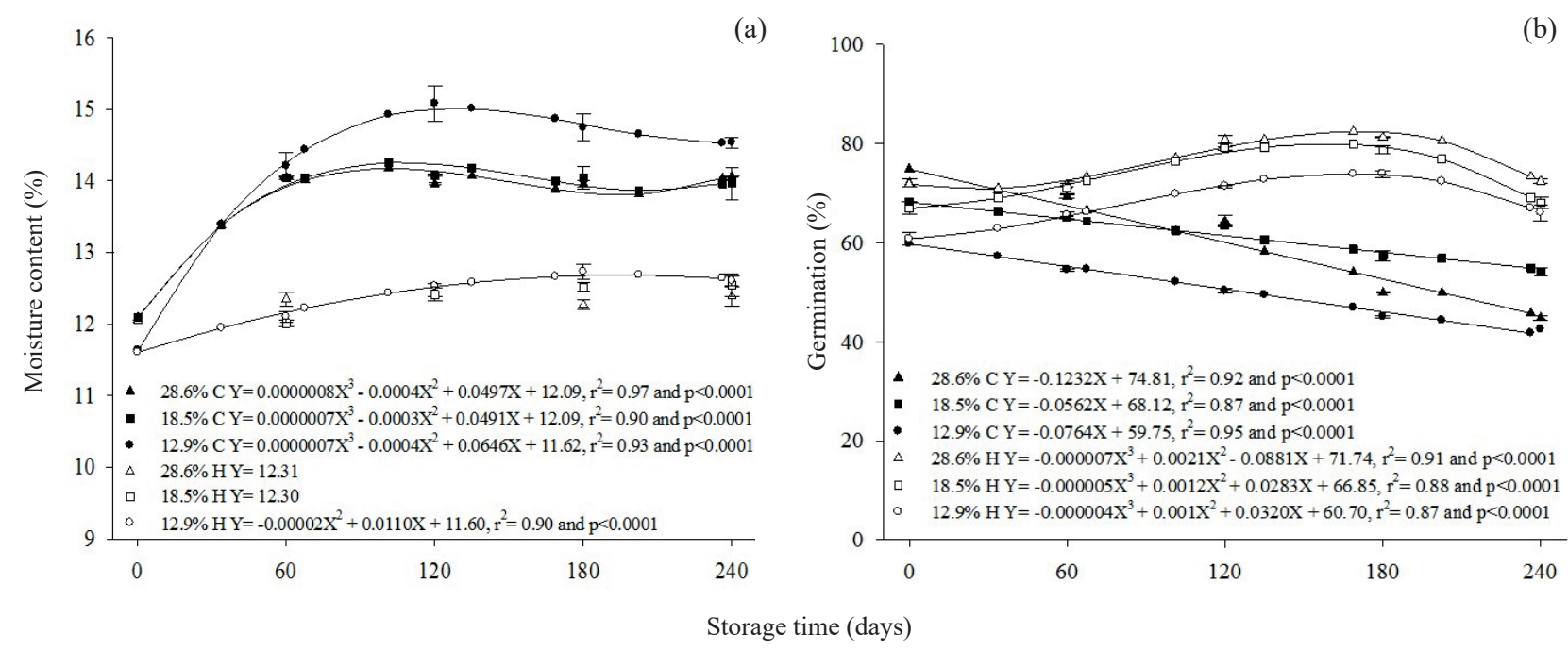

Figure 2. Moisture content (a) and germination percentage (b) of wheat seeds (BRS Parrudo cultivar) harvested at different moisture contents $(28.6 \%, 18.5 \%$ and $12.9 \%)$ and stored in the conventional $(\mathrm{C})$ and hermetic $(\mathrm{H})$ systems, under natural conditions, for 240 days.

gaseous exchange with the environment impossible, stabilizing the internal atmosphere and, consequently, the moisture content of the seeds. On the other hand, the moisture content of the seeds stored in a conventional system is directly influenced by the atmospheric conditions of the storage place and, therefore, follows the oscillations of relative air humidity (Jonfia-Essien et al. 2010).

However, over time and for both storage systems, seeds harvested with a moisture content of $12.9 \%$ had higher moisture contents than the other harvest conditions for both the storage systems, indicating that the delay in harvest provides a decrease in quality. This fact may be attributed to degraded grains, which tend to reach hygroscopic equilibrium at higher moisture contents (Peske \& Barros 2006).

The germination of the wheat seeds kept in the hermetic system increased up to 180 days of storage for all moisture contents at harvest and, after that, the germination percentage decreased, but always presenting higher values than those stored in the conventional system (Figure 2b). This result may be due to seed dormancy, which, in the case of wheat, is higher soon after harvest, because of the presence of germination-inhibiting hormones such as abscisic acid (Tuttle et al. 2015). The dormancy break occurs along the storage process, what causes an increase in the percentage of germinated seeds. Similar results were obtained by Rupollo et al. (2004) and Petrenko
(2014), studying oat and wheat seeds, which verified an increase in seed germination during the hermetic storage, with a subsequent reduction in germination at 180 and 360 days of storage, respectively. Freiberg et al. (2017) also verified a reduction in the germination percentage of wheat seeds during 240 days under conventional storage.

The hermetic system maintained the increase in the percentage of seed germination for a longer time than the conventional system. This fact may be related to the reduction of degradation rates in this system, due to the higher concentration of $\mathrm{CO}_{2}$ in the intergranular atmosphere (Jonfia-Essien et al. 2010), which reduces seed respiration, thus slowing down the degradation process. This was also demonstrated by Aguiar et al. (2015), studying rice seeds stored under high $\mathrm{CO}_{2}$ concentrations. They observed a higher germination percentage during storage.

The seeds stored in the conventional system showed a linear decrease in the percentage of germination throughout storage for all harvest conditions (Figure 2b). Seeds harvested late presented a lower performance during the entire storage period. However, harvest with a moisture content of $28.6 \%$ presented a more pronounced fall in germination, possibly due to damages during processing and drying.

This suggests that the process of seed deterioration was more pronounced than the process of dormancy breaking. This may happen because, 
during conventional storage, the seeds are subject to air temperature and relative humidity fluctuations, which, consequently, cause fluctuations in their moisture content. This process of increasing and reducing moisture content results in damage to the tegument, compromising the physiological quality (Copeland \& McDonald 1995). These results agree with those obtained by Strelec et al. (2010) and Chattha et al. (2012), which verified a decrease in the germination percentage of wheat seeds stored in the conventional system over 12 months.

Harvest with a moisture content of $12.9 \%$ resulted in lower germination values than the other treatments, during the entire storage period and in both storage systems, what evidences the damages caused by the delay in harvest. These results are similar to those found by Tunes et al. (2010a) and Diniz et al. (2013), which verified a decrease in the germination of barley and soybean seeds, respectively, with harvest delay. According to the authors, the germination reduction is associated with an increment in the incidence of fungi and an increase of the deterioration process, due to the adverse conditions that the seeds are exposed in the field, such as intermittent wet and dry periods, besides temperature oscillations, which lead to greater losses during storage.

In addition, the lower germination percentages observed for seeds harvested late in both storage systems may be related to the higher moisture content when hygroscopic equilibrium is reached. Seeds stored with higher moisture contents may present more pronounced reductions on germination, as reported by Freitas et al. (2011), in a research with bean seeds stored under hermetic conditions. According to the authors, this greater loss is due to the higher moisture content of the seeds, which maintains the respiratory rates, culminating in a higher temperature of the seed mass, inducing, besides a greater consumption of the reserves, a suitable environment for the development of fungi and insects.

According to the first germination count, the percentage of normal seedlings from wheat seeds stored in the hermetic system increased up to 120 days of storage, while seeds stored under the conventional system showed an increase in the percentage of normal seedlings only up to 60 days, after which, for both systems, there was a decrease in the values (Figure 3a). However, the hermetic system provided a higher percentage of normal seedlings, when compared to the conventional system, throughout the storage period. These results are in agreement with those found by Freiberg et al. (2017), who observed an increase in the values of the first germination count of wheat seeds up to 120 days of conventional storage, after which the values were also reduced. Harvest delay negatively influenced the first germination count values for both storage systems, corroborating the results observed by Tunes et al. (2010a), in barley seeds, with harvest delay.

The germination speed of the seeds stored in the hermetic system increased up to 120 days. After this period, a reduction in the values was observed (Figure $3 b$ ), although they were always higher than

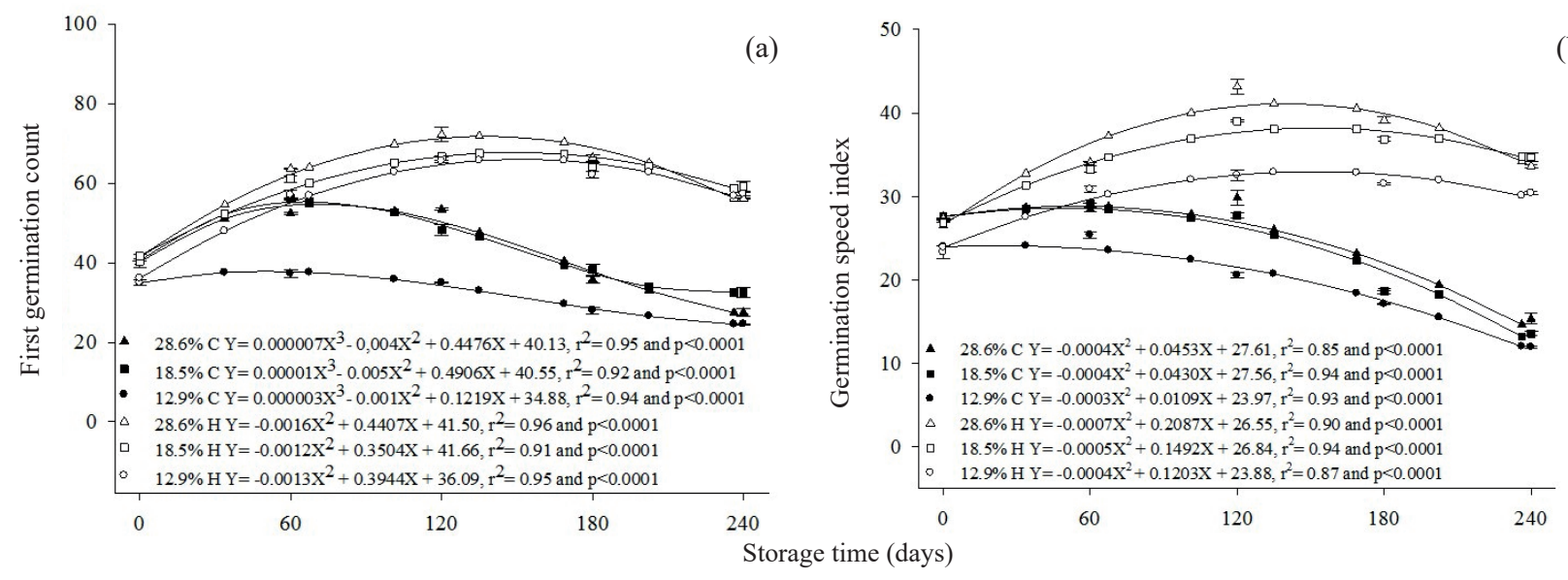

(b)

Figure 3. First germination count (a) and germination speed index (b) of wheat seeds (BRS Parrudo cultivar) harvested at different moisture contents $(28.6 \%, 18.5 \%$ and $12.9 \%)$ and stored in the conventional $(\mathrm{C})$ and hermetic $(\mathrm{H})$ systems, under natural conditions, for 240 days. 
those obtained in the conventional system, throughout the storage period. The seeds kept in the conventional system showed a reduction in germination speed from 60 days of storage. These results are in agreement with those obtained by Smaniotto et al. (2014), which observed a reduction in the germination speed index of soybean seeds stored in the conventional and hermetic systems, for nine months. Among the harvests, the one with a moisture content of $12.9 \%$ provided seeds with lower germination speed along the storage for both systems. Similar results were found by Tunes et al. (2010a), in barley seeds, with harvest delay.

The reduction of vigor for the seeds stored in the conventional system, verified after 60 days in the first germination count and germination speed index, shows that these tests presented a low sensitivity to measure the vigor of the seeds, since they take into account the speed germination of the seeds. This occurs because the reduction of germination speed is not among the first events related to deterioration, making it impossible to detect seed vigor more accurately (Dias 2001).

According to the accelerated aging test, the percentage of normal seedlings from the seeds harvested with moisture contents of $28.6 \%$ and $18.5 \%$ was maintained in the hermetic system up to 120 days of storage. After this period, there was a decrease in the observed values (Figure 4a). These results are similar to those obtained by Tunes et al. (2010b), which verified an increase in the percentage of normal barley seedlings submitted to the accelerated aging test after 180 days of storage in a cold chamber. On the other hand, seeds harvested with a moisture content of $12.9 \%$, even stored in the hermetic system, showed a linear decrease in the percentage of normal seedlings during the storage period, evidencing the deterioration suffered in the field due to inadequate relative humidity conditions and temperature, in addition to a possible greater fungus contamination.

Seeds stored under the conventional system showed a linear decrease in the percentage of normal seedlings during the storage period for all harvest conditions. Also, the conventional system provided a lower percentage of normal seedlings, when compared to the hermetic system, for the different harvest conditions, from 60 days after storage until the end of the experiment. Similar results were obtained by Naguib et al. (2011), who verified, through the accelerated aging test, the reduction of the percentage of wheat normal seedlings during 18 months of storage.

The results obtained in the cold test show that the seeds stored in the hermetic system, for all moisture contents at harvest, showed an increase in the percentage of normal seedlings up to 120 days after storage. After this period, there was a decrease in the observed values (Figure $4 \mathrm{~b}$ ). The seeds stored under the conventional system showed a linear decrease in the percentage of normal seedlings during the entire storage period, presenting lower values, when compared to the hermetic system, for
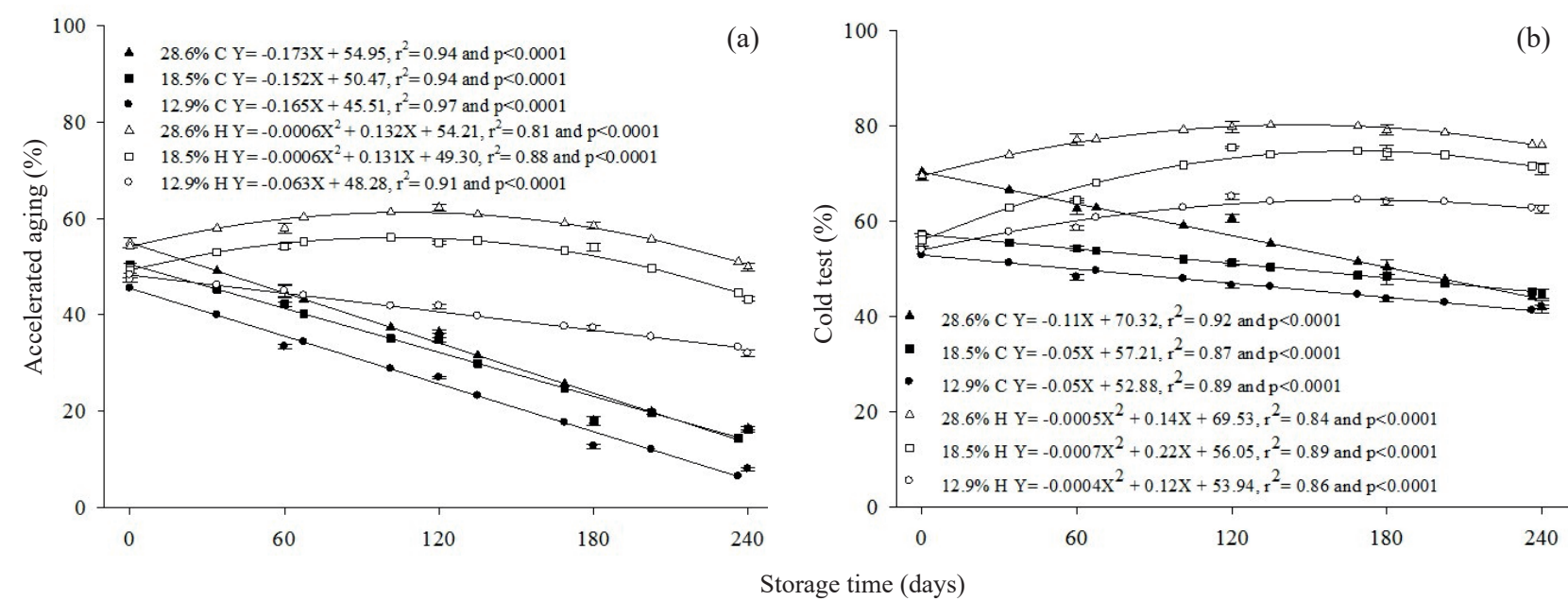

Figure 4. Germination of wheat seeds (BRS Parrudo cultivar) harvested at different moisture contents $(28.6 \%, 18.5 \%$ and $12.9 \%)$ and stored in the conventional $(\mathrm{C})$ and hermetic $(\mathrm{H})$ systems, under ambient conditions, during 240 days, subjected to accelerated aging (a) and cold (b) tests. 
the different harvest conditions. Also, harvest delay negatively influenced the percentage of normal seedlings for both systems, during the entire storage period. These results are in agreement with those obtained by Timóteo \& Marcos-Filho (2013), who verified, by applying the cold test, a reduction in the vigor of corn seeds during 15 months of conventional storage.

However, the cold test presented values close to those obtained in the germination test, indicating a low sensitivity of the method to evaluate the vigor of wheat seeds (Figures 2a and 3b). Similar results were verified by Fanan et al. (2006), in seeds of the same product. According to the authors, this fact is due to the minimum temperature for the germination of wheat $\left(3-5^{\circ} \mathrm{C}\right)$, which is lower than that used in the cold test $\left(10^{\circ} \mathrm{C}\right)$. The temperature of $10^{\circ} \mathrm{C}$ allows the seeds to germinate during the period of cooling, thus increasing the number of normal seedlings until the count.

The accelerated aging test provided better conditions for evaluating the vigor of wheat seeds submitted to different factors (Figure 3a). According to Fanan et al. (2006), a high temperature combined with a high relative air humidity increases the speed of seed degradation, allowing a more accurate classification of different seed lots, in relation to their vigor.

Seedlings from seeds harvested with $28.6 \%$ of moisture content and stored in the hermetic system presented the highest values of shoot length during the entire storage period (Figure 5a). Among the storage systems, the hermetic one provided seedlings with a greater shoot length during storage, when compared to the conventional system. Similar results were found by Tunes et al. (2010b), in barley seeds, who observed an increase in the shoot length of seedlings up to 120 days of storage in a cold chamber. There was an increase in the length of seedlings from seeds stored in the hermetic system, for all harvest conditions, up to 120 days of storage, after which the values were reduced. Regarding the conventional system, there was a linear decrease in shoot length and dry matter of the seedlings throughout the storage period. Harvest delay provided the shortest shoot length for both systems over the storage time.

The dry matter transfer test showed that the seeds harvested with a moisture content of $28.6 \%$ and stored in the hermetic system showed a higher capacity to transfer nutrients to the embryonic axis, since they presented higher values of dry matter during the whole storage period (Figure $5 b$ ). The dry matter transfer of seeds stored in the hermetic system increased up to 120 days of storage for all harvests, and after that the observed values were reduced. The dry matter transfer capacity of the seeds stored in the conventional system declined linearly throughout the storage for all harvests, but the harvest with a moisture content of $12.9 \%$ had the lowest values. However, even in the conventional system, seeds harvested earlier $(28.6 \%)$ provided a higher amount of dry matter per seedling during the whole storage period, when compared to seeds harvested late $(12.9 \%)$, even in the hermetic storage.

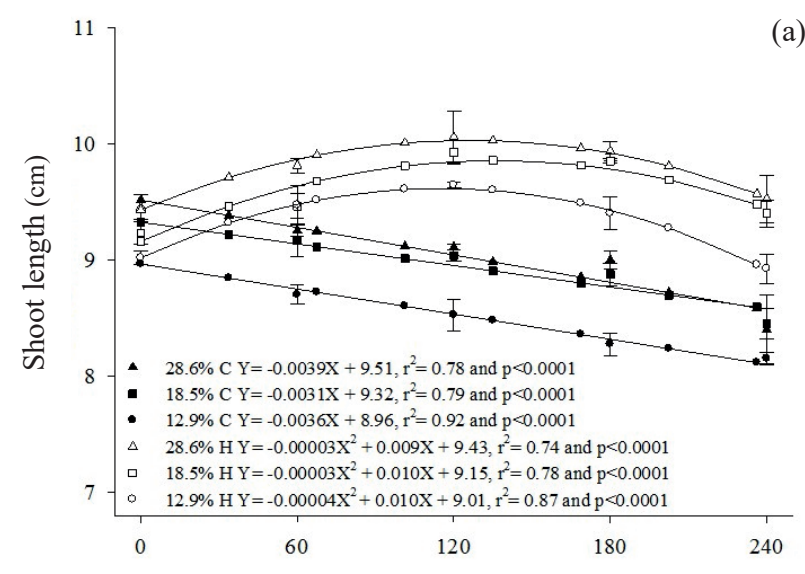

(a)

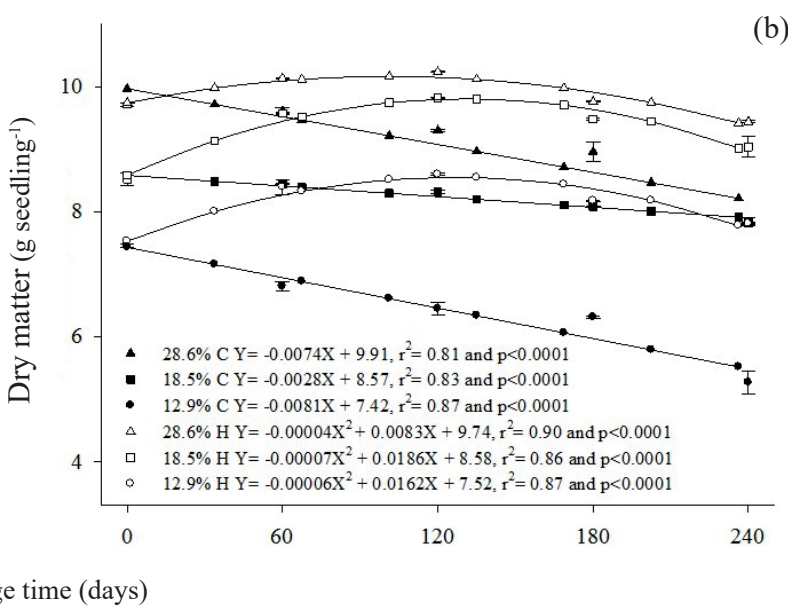

Figure 5. Shoot length (a) and dry matter (b) of wheat seedlings (BRS Parrudo cultivar) harvested at different moisture contents (28.6\%, $18.5 \%$ and $12.9 \%$ ) and stored in the conventional $(\mathrm{C})$ and hermetic $(\mathrm{H})$ systems, under ambient conditions, for 240 days. 


\section{CONCLUSIONS}

1. Harvest delay, as well as storage time, reduces the physiological performance of wheat seeds;

2. Seeds stored in the hermetic system present a better physiological performance, when compared to those stored in the conventional system;

3. Harvesting wheat seeds with moisture contents between $18.5 \%$ and $28.6 \%$, combined with the hermetic storage, increases the physiological performance of seeds during eight months of storage.

\section{REFERENCES}

AGUIAR, R. W. S. et al. Effect of carbon dioxide on quality of rice seeds. Bioscience Journal, v. 31, n. 5, p. 1413-1422, 2015.

BRASIL. Ministério da Agricultura, Pecuária e Abastecimento. Regras para análise de sementes. Brasília, DF: MAPA/SDA/ACS, 2009.

CHATTHA, S. H. et al. Effect of different packing materials and storage conditions on the viability of wheat seed (TD1 variety). Science, Technology and Development, v. 31, n. 1, p. 10-18, 2012.

COMPANHIA NACIONAL DE ABASTECIMENTO (Conab). Acompanhamento da safra brasileira: grãos, décimo primeiro levantamento, agosto 2017. Brasília, DF: Conab, 2017.

COPELAND, L. O.; McDONALD, M. B. Seed science and technology. New York: Chapman \& Hall, 1995.

CUNHA, G. R. da; CAIERÃO, E. (Eds.). Informações técnicas para trigo e triticale: safra 2015. Brasília, DF: Embrapa, 2014.

DELIBERALI, J. et al. Efeitos de processo de secagem e tempo de armazenamento na qualidade tecnológica de trigo. Ciência e Agrotecnologia, v. 34, n. 5, p. 1285-1292, 2010.

DIAS, D. C. Maturação de sementes. Seed News, v. 5, n. 6, p. 3-4, 2001.

DINIZ, F. O. et al. Physiological quality of soybean seeds of cultivars submitted to harvesting delay and its association with seedling emergence in the field. Journal of Seed Science, v. 35, n. 2, p. 147-152, 2013.

FANAN, S. et al. Avaliação do vigor de sementes de trigo pelos testes de envelhecimento acelerado e de frio. Revista Brasileira de Sementes, v. 28, n. 2, p. 152-158, 2006.
FARRER, D. et al. Delayed harvest effect on soft red winter wheat in the southeastern USA. Agronomy Journal, v. 98, n. 1, p. 588-595, 2006.

FREIBERG, J. A. et al. Physiological performance of wheat seeds treated with micronutrients and protection products during storage. Journal of Seed Science, v. 39, n. 2, p. 182-188, 2017.

FREITAS, R. S. et al. Quality of beans stored under hermetic conditions. Engenharia Agrícola, v. 31, n. 6, p. 1136-1149, 2011.

JONFIA-ESSIEN, W.; NAVARRO, S.; VILLERS, P. Hermetic storage: a novel approach to the protection of cocoa beans. African Crop Science Journal, v. 18, n. 2, p. 59-68, 2010.

LOEFFLER, T. M.; MEYER, J. L.; BURRIS, J. S. Comparação dos dois processos de ensaio para utilização em estudos de secagem do milho. Ciência e Tecnologia de Sementes, v. 13, n. 1, p. 653-658, 1985.

MAGUIRE, J. D. Velocidade de germinação na seleção e avaliação de emergência e vigor de plântulas. Crop Science, v. 2, n. 1, p. 176-177, 1962.

MARCOS-FILHO, J.; CÍCERO, S. M.; SILVA, W. R. Avaliação da qualidade de sementes. Piracicaba: FEALQ, 1987.

NAGUIB, N. A.; MOHAMED, E. A. I.; EL-AIDY, N. A. Effect of storage period and packaging material on wheat (Triticum aestivum L.) seed viability and quality. Egyptian Journal of Agricultural Research, v. 89, n. 4, p. 1481-1497, 2011.

PESKE, S. T.; BARROS, A. C. S. A. Produção de sementes. In.: PESKE. S. T.; LUCCA FILHO, O. A.; BARROS, A. C. S. A. Sementes: fundamentos científicos e tecnológicos. 2 ed. Pelotas: Ed. UFPel, 2006.

PETRENKO, V. Influence of storage conditions on germination of winter wheat seeds (Triticum aestivum $\mathrm{L}$.) in relation to agriculture systems. Žemés Ükio Mokslai, v. 21, n. 3, p. 173-180, 2014.

RUPOLLO, G. et al. Sistemas de armazenamentos hermético e convencional na conservabilidade de grãos de aveia. Ciência Rural, v. 34, n. 6, p. 1715-1722, 2004.

SMANIOTTO, T. A. de S. et al. Qualidade fisiológica das sementes de soja armazenadas em diferentes condições. Revista Brasileira de Engenharia Agrícola e Ambiental, v. 18, n. 4, p. 446-453, 2014.

STRELEC, I. et al. Influence of temperature and relative humidity on grain moisture, germination and 
vigour of three wheat cultivars during one year storage. Poljoprivreda, v. 16, n. 2, p. 20-24, 2010.

TIMÓTEO, T. S.; MARCOS-FILHO, J. Seed performance of different corn genotypes during storage. Journal of Seed Science, v. 35, n. 2, p. 207-215, 2013.

TUNES, L. M. et al. Diferentes épocas de colheita e qualidade fisiológica de sementes de cevada. Revista Brasileira de Sementes, v. 32, n. 2, p. 42-48, 2010a.

TUNES, L. M. et al. Armazenabilidade de sementes de cevada colhidas em diferentes épocas. Bioscience Journal, v. 26, n. 3, p. 403-412, 2010 b.
TUTTLE, K. M. et al. Grain dormancy loss is associated with changes in ABA and GA sensitivity and hormone accumulation in bread wheat, Triticum aestivum (L.). Seed Science Research, v. 25, n. 2, p. 179-193, 2015.

UNITED STATES DEPARTMENT OF AGRICULTURE (USDA). Grain: world markets and trade. Washington, DC: USDA, 2016.

WALIA, K. B. H. Drought stress delays endosperm development and misregulates genes associated with cytoskeleton organization and grain quality proteins in developing wheat seeds. Plant Science, v. 240, n. 1, p. 110-119, 2015. 